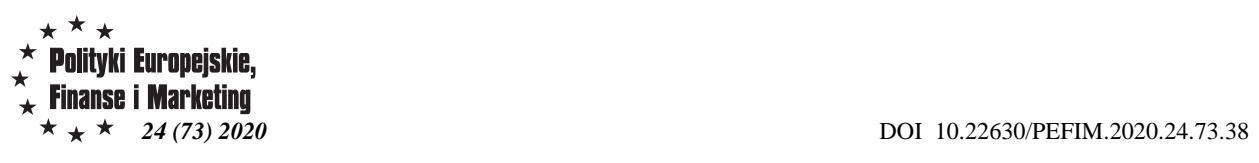

Tomasz Rokicki,

Stanistaw Bereziński

Warsaw University of Life Sciences WULS - SGGW

\title{
FINANCING OF LINEAR ROAD INFRASTRUCTURE IN POLAND
}

The main purpose of the paper was to identify and present the situation and changes in the level of expenditure on public roads in Poland, taking into account the division of the country into voivodships. The data concerned the period from 2005 to 2017. Sources of materials were the analysis of available literature in the field of road transport, legal acts, data from the CSO database. The comparative method was used in the paper, dynamics indicators were evaluated, the Gini concentration coefficient was calculated and the degree of concentration was presented using the Lorenz curve. Pearson's linear correlation coefficients were also used. A descriptive, tabular and graphic method were used to present the results. Investment outlays on roads apply to both the construction of new roads and the repair of existing ones. Between 2005-2017, the length of public roads in Poland increased by $11 \%$ to $422,000 \mathrm{~km}$. Changes in individual voivodships and in subsequent years varied. The largest increase in road length occurred in Podlaskie and Lublin, while the smallest was in Opole. The largest expenditure on public roads was incurred in 20092011, which was related to the preparation for the Euro 2012 football tournament, which took place in Poland and Ukraine. Investment outlays were related to the level of economic development of voivodships and the resources of public roads. The only exception to this rule occurred in 2009-2011, when many road investments were centrally financed by the government.

Key words: infrastructure, road transport, road expenditure, European funds JEL Codes: E22, H41, H54, O18, R4

\section{Introduction}

The basic condition for the existence of every economic system, both on a local and global scale, is to ensure the possibility of moving products of human work. Movement of goods is conditioned by the functioning of the transport system, consisting of elements of point and line infrastructure [Bailey et al. 2019]. The importance of transport and guidelines for infrastructure development in Poland are described in the latest Transport Sustainable Development Strategy until 2030. As indicated in the aforementioned document, in Poland the dominant type of transport is road transport, which transports $80 \%$ of freight. The quality of roadways is therefore crucial for the functioning of the country's economy. Although the condition of roads in Poland in general is improving, as evidenced by, for example, an improvement in the scoring in the Global Competitiveness Ranking published by the World Economic Forum (improvement in rating from 2.5 points in 2012 to 4.1 points in 2017 in the road infrastructure category), infrastructure is still unsatisfactory [World Economic Forum 2017]. 
Pursuant to the Act on Public Roads [1985] and executive acts for this Act [Rozporządzenie ... 1999], public roads in Poland are divided into classes and categories. The classes describe technical and functional requirements. In turn, categories are closely related to road financing and management. The Act on public roads [1985] distinguishes the following categories of roads in Poland: national, provincial, poviat and municipal. As shown from data presented in the Strategy, over $95 \%$ of roads are managed by local government units. It is worth noting that although national roads constitute only $4.6 \%$ of the total roads, they support as much as $40 \%$ of traffic, performing $85 \%$ of freight and $75 \%$ of passenger transport [Strategia... 2019].

The costs of building and maintaining road line infrastructure in Poland are borne by the central and local government authorities, which, depending on the category of road, are responsible for its management. In the case of national roads, the management is carried out by the minister responsible for transport through the General Director for National Roads and Motorways. An additional instrument for the implementation of road investments is the National Road Fund [Ustawa... 1994]. The funds used come from the national budget, in particular from taxes, fuel charges, etc. Funds within the European Union are a separate source of funding, in particular funds under the already completed TEN-T (Transeuropean Transport Network) project and CEF project (Connecting Europe Facility) replacing it from 2016 [Tyc 2017].

In the case of local government roads, the basic source of funds for road maintenance and investments is the unit's own budget. From the end of 2018, local governments can also use the Local Government Road Fund fed with money transferred from the state budget, the National Fund for Environmental Protection and Water Management and the State Forests National Forest Holding [Ustawa ... 2018]. In the same year, the Mosty Plus program was launched to help local governments carry out expensive bridge crossings. However, due to limited resources in the budgets of local government units, the most important source of road financing are funds from the European Union structural funds [Strategia... 2019, Tyc 2017].

Despite access to various sources of financing, especially at the level of local governments, the funds allocated to road infrastructure are not sufficient, and disparities in the quality and equipment of roads in Poland in regional terms are very high [GDDKiA 2019].

\section{Aim, materials and methods}

The main purpose of the paper was to identify and present the situation and changes in the level of expenditure on public roads in Poland. Public roads include all roads with a hard surface and a ground surface. For the needs of the paper, specific objectives were formulated, i.e. determining the degree of concentration of investment expenditure in Poland, showing the dynamics of changes in the length of public roads and their density, determining the relationship between the level of investment expenditure on public roads and economic growth. The research concerned Poland, taking into account the division into voivodships. The research area was selected in a targeted manner. The data concerned 2005-2017. The sources of materials were the analysis of available literature in the field of road transport, legal acts, data from the CSO database. The comparative method was used in the paper, dynamics indicators were evaluated, the Gini 
concentration coefficient was calculated and the degree of concentration was presented using the Lorenz curve. Pearson's linear correlation coefficients were also used. A descriptive, tabular and graphic method was used to present the test results.

\section{Research results and discussion}

The length of public roads varied in individual voivodships. In 2017, the most public car roads were in the Masovia (54.7 thousand km), Greater Poland (40.8 thousand $\mathrm{km}$ ) and Lublin (37.0 thousand $\mathrm{km}$ ) voivodships, while the least were in the Opole voivodship (10.5 thousand $\mathrm{km}$ ), Lubusz (15.5 thousand $\mathrm{km}$ ) and Świętokrzyskie. However, the dynamics of changes differed in individual voivodships. In the years 2005-2017, the most public roads arrived in the Podlasie $(37.5 \%)$ and Lublin $(25.3 \%)$ provinces (Table 1). They were also voivodships of Eastern Poland bordering Belarus and Ukraine, i.e. important trade partners. In turn, the length of roads in Opole and Silesia voivodships slightly decreased. Differences in the dynamics of the length of public roads in individual periods can also be noticed. In virtually all voivodships, the number of motorways increased in the years 2009-2011, which was the period immediately preceding the European Football Championships Euro 2012, which were organized in Poland and Ukraine. This was associated with allocating large expenditures to adapt roads to European requirements. Both before and after this period, the increase in the length of roads was much smaller. There were also voivodships in which the road length was reduced at certain times. In 2005-2017, the total length of public roads in Poland increased by $11 \%$.

Table 1. Dynamics indicators with a variable basis, for the length of public roads in Poland in 2005-2017 (first year in a given period $=100$ )

\begin{tabular}{|l|c|c|c|c|c|}
\hline \multirow{2}{*}{\multicolumn{1}{c|}{ Voivodships }} & \multicolumn{5}{c|}{ Dynamics indicators in years } \\
\cline { 2 - 6 } & $\mathbf{2 0 0 5 - 2 0 0 8}$ & $\mathbf{2 0 0 9 - 2 0 1 1}$ & $\mathbf{2 0 1 2 - 2 0 1 4}$ & $\mathbf{2 0 1 5 - 2 0 1 7}$ & $\mathbf{2 0 0 5 - 2 0 1 7}$ \\
\hline Podlaskie & 99,68 & 131,05 & 103,55 & 101,67 & 137,53 \\
\hline Lublin & 102,14 & 114,71 & 101,08 & 105,79 & 125,28 \\
\hline Lubusz & 101,33 & 102,55 & 108,88 & 104,22 & 117,92 \\
\hline Subcarpathia & 100,95 & 102,58 & 109,36 & 101,36 & 114,78 \\
\hline Pomerania & 100,32 & 113,30 & 103,16 & 97,50 & 114,32 \\
\hline West Pomerania & 102,43 & 106,31 & 103,21 & 100,63 & 113,10 \\
\hline Lesser Poland & 100,86 & 105,72 & 99,32 & 104,90 & 111,09 \\
\hline Kuyavia-Pomerania & 100,66 & 105,52 & 100,74 & 102,70 & 109,90 \\
\hline Masovia & 99,76 & 106,87 & 100,52 & 102,31 & 109,65 \\
\hline Łódź & 99,96 & 110,09 & 99,55 & 99,54 & 109,05 \\
\hline Lower Silesia & 100,24 & 105,35 & 99,80 & 100,64 & 106,06 \\
\hline Śsiętokrzyskie & 100,09 & 101,83 & 100,45 & 101,95 & 104,37 \\
\hline Greater Poland & 101,64 & 99,12 & 100,84 & 101,26 & 102,88 \\
\hline Warmia-Masuria & 99,66 & 106,98 & 99,28 & 96,92 & 102,58 \\
\hline Silesia & 98,73 & 107,06 & 97,09 & 96,99 & 99,53 \\
\hline Opole & 98,74 & 105,43 & 96,47 & 95,72 & 96,13 \\
\hline Poland & 100,49 & 107,55 & 101,16 & 101,27 & 110,71 \\
\hline
\end{tabular}

Source: authors' own study based on CSO data.

The length of public roads often depends on the area of the voivodship. As a rule, larger voivodships had more kilometers of roads. Therefore, the more appropriate measure is the density of public roads expressed per $100 \mathrm{~km}^{2}$. The highest density of public roads in 2017 occurred in the following provinces: Lesser Poland, Silesia and 
Masovia (Table 2). They were the most developed regions of the country. In turn, the weakest road network was in the West Pomeranian, Warmian-Masurian and Lubusz voivodships. The first two local government units were characterized by the occurrence of terrain obstacles in the form of lakes. When assessing infrastructure, attention should be paid to the dynamics of change. It was the same as in the case of the length of roads.

Table 2. Density of public road networks in Poland in 2005-2017

\begin{tabular}{|c|c|c|c|c|c|}
\hline \multirow{2}{*}{ Voivodships } & \multicolumn{5}{|c|}{ Length of public roads per $100 \mathrm{~km}^{2}$ by year } \\
\hline & 2005 & 2008 & 2011 & 2014 & 2017 \\
\hline Lesser Poland & 187,50 & 188,60 & 199,90 & 198,00 & 207,70 \\
\hline Silesia & 203,60 & 200,30 & 215,20 & 208,30 & 202,00 \\
\hline Masovia & 140,20 & 139,90 & 149,50 & 150,20 & 153,80 \\
\hline Kuyavia-Pomerania & 139,00 & 139,90 & 147,60 & 148,70 & 152,70 \\
\hline Świętokrzyskie & 143,60 & 143,50 & 146,30 & 146,70 & 149,60 \\
\hline Lublin & 117,60 & 120,10 & 137,80 & 139,20 & 147,30 \\
\hline Łódź & 131,10 & 131,10 & 144,30 & 143,70 & 143,00 \\
\hline Greater Poland & 133,10 & 135,30 & 134,10 & 135,20 & 136,90 \\
\hline Podlaskie & 97,00 & 96,70 & 126,80 & 131,30 & 133,40 \\
\hline Pomerania & 108,30 & 108,70 & 123,10 & 127,00 & 123,70 \\
\hline Lower Silesia & 112,40 & 112,70 & 118,70 & 118,50 & 119,30 \\
\hline Subcarpathia & 102,00 & 103,40 & 105,60 & 116,00 & 117,50 \\
\hline Opole & 115,70 & 114,30 & 120,50 & 116,20 & 111,20 \\
\hline Lubusz & 93,70 & 95,00 & 97,40 & 106,00 & 110,50 \\
\hline Warmia-Masuria & 89,50 & 89,10 & 95,40 & 94,70 & 91,90 \\
\hline West Pomerania & 76,50 & 78,40 & 83,30 & 86,00 & 86,60 \\
\hline Poland & 122,00 & 122,60 & 131,80 & 133,40 & 135,10 \\
\hline
\end{tabular}

Source: authors' own study based on CSO data

Investment outlays for public roads in 2005-2017 accounted for almost PLN 288 billion (Table 3 ). Investment outlays in this case were incurred in order to create new roads or improve them (conversion, extension, reconstruction or modernization).

Table 3. Investment expenditures for public roads in Poland in 2005-2017

\begin{tabular}{|l|c|c|c|c|c|}
\hline \multirow{2}{*}{ Voivodships } & \multicolumn{4}{|c|}{ Investment expenditures for public roads in the years (PLN million) } \\
\cline { 2 - 6 } & $\mathbf{2 0 0 5 - 2 0 0 8}$ & $\mathbf{2 0 0 9 - 2 0 1 1}$ & $\mathbf{2 0 1 2 - 2 0 1 4}$ & $\mathbf{2 0 1 5 - 2 0 1 7}$ & $\mathbf{2 0 0 5 - 2 0 1 7}$ \\
\hline Masovia & 7102,00 & 8128,90 & 8167,40 & 9512,00 & 32910,30 \\
\hline Silesia & 5974,00 & 14147,20 & 5959,10 & 4907,40 & 30987,70 \\
\hline Łódź & 3293,00 & 7177,10 & 11851,80 & 4647,70 & 26969,60 \\
\hline Lower Silesia & 5735,00 & 7677,30 & 3482,90 & 5878,10 & 22773,30 \\
\hline Greater Poland & 4064,00 & 7315,50 & 5264,80 & 5324,50 & 21968,80 \\
\hline Subcarpathia & 1729,00 & 8236,10 & 7767,20 & 4022,10 & 21754,40 \\
\hline Lesser Poland & 4588,00 & 6430,30 & 5333,70 & 4296,90 & 20648,90 \\
\hline Kuyavia-Pomerania & 2959,00 & 7596,20 & 2754,10 & 4857,00 & 18166,30 \\
\hline Pomerania & 4481,00 & 4031,10 & 2303,60 & 5117,10 & 15932,80 \\
\hline Warmia-Masuria & 1985,00 & 4420,60 & 3110,50 & 5326,20 & 14842,30 \\
\hline Lublin & 2225,00 & 3294,80 & 4978,80 & 3812,90 & 14311,50 \\
\hline Lubusz & 1622,00 & 7035,40 & 2299,40 & 2034,90 & 12991,70 \\
\hline West Pomerania & 2515,00 & 3648,10 & 1397,30 & 3358,30 & 10918,70 \\
\hline Podlaskie & 1000,00 & 2829,30 & 3424,00 & 2502,40 & 9755,70 \\
\hline Świętokrzyskie & 1264,00 & 3179,20 & 1808,90 & 2671,70 & 8923,80 \\
\hline Opole & 778,00 & 1092,80 & 848,80 & 1057,70 & 3777,30 \\
\hline Poland & 51309,00 & 96238,90 & 70752,30 & 69326,90 & 287627,10 \\
\hline
\end{tabular}

Source: authors' own study based on CSO data. 
Analyzing capital expenditure on roads divided into periods, it can be stated that the largest expenses were incurred in 2009-2011 immediately preceding the European Football Championships organized in 2012 in Poland and Ukraine. Both before and after this period expenses were lower. The largest expenditure on public roads was incurred in the Masovia, Silesia and Łódź voivodships, while the smallest was in the Opole, Świętokrzyskie and Podlaskie voivodships. It can therefore be concluded that the economically better voivodships spent more on roads. In part, this statement can be justified by the financial capabilities of individual self-governments, which when applying for EU funds had to set up their own contribution. However, this claim requires justification as a result of the use of research methods.

The Gini coefficient was used to determine the concentration of investment outlays in Poland. The data concerned 2017, while the number of observations was 16 (all voivodships). The Gini coefficient calculated from the sample was 0.28 , while the estimated coefficient for the population was 0.30 . This means a poor concentration of investment outlays on public roads in Poland. In addition, this diversity is represented by the Lorenz concentration curve (Figure 1). In 2005, Gini coefficients were higher, respectively 0.34 from the sample and 0.36 estimated for the population. This means that the concentration of investment outlays on public roads in voivodships decreased. They were more evenly distributed due to the area and economic development, even if the potential of individual voivodships was not assessed.
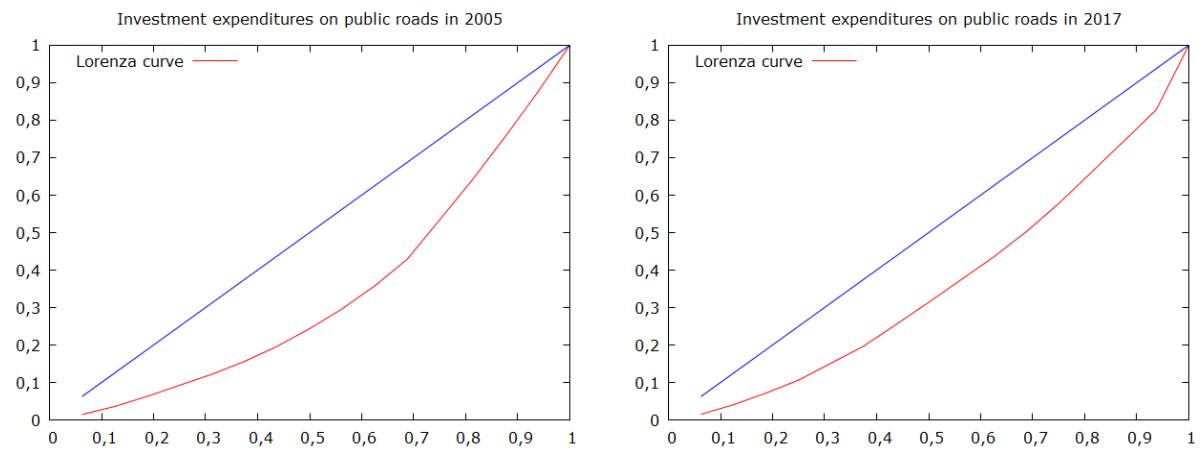

Figure 1. Lorenz concentration curve for investment expenditures on public roads in Poland in 2005 and 2017 Source: authors' own study based on CSO data.

In order to determine the relationship between the amount of investment outlays on public roads in Polish voivodships and the basic parameters related to road linear infrastructure and economy, Pearson's linear correlation coefficients were calculated (Table 4). $\mathrm{P}=0.05$ was adopted as the limit of significance level. Important results are marked in bold in Table 4. Correlation coefficients were calculated for Polish voivodships in individual periods, as well as for the entire 2005-2017 range. The study tried to check the correlation, which does not indicate that a given factor affects another, but that there is a strong or weak relationship between them. 
Table 4. Investment expenditures for public roads in Poland in 2005-2017

\begin{tabular}{|c|c|c|c|c|c|}
\hline \multirow[b]{2}{*}{ Parameters } & \multicolumn{5}{|c|}{ Pearson's linear correlation coefficients in years } \\
\hline & $\begin{array}{c}2005- \\
2008\end{array}$ & $\begin{array}{l}2009- \\
2011\end{array}$ & $\begin{array}{l}2012- \\
2014\end{array}$ & $\begin{array}{l}2015- \\
2017\end{array}$ & 2005 \\
\hline \multicolumn{6}{|c|}{ Correlation coefficients between investment expenditures for public roads and } \\
\hline GDP per capita & 0,796 & $\mathbf{0 , 4 2 7}$ & $\mathbf{0 , 3 1 3}$ & 0,657 & $\mathbf{0 , 4 9 2}$ \\
\hline p-value & 0,001 & $\mathbf{0 , 0 0 3}$ & $\mathbf{0 , 0 3 0}$ & $\mathbf{0 , 0 0 1}$ & $\mathbf{0 , 0 0 1}$ \\
\hline Sold production of industry per capita & $\mathbf{0 , 7 6 2}$ & $\mathbf{0 , 6 1 0}$ & 0,258 & $\mathbf{0 , 5 0 6}$ & $\mathbf{0 , 4 8 4}$ \\
\hline p-value & 0,001 & $\mathbf{0 , 0 0 1}$ & 0,076 & 0,001 & $\mathbf{0 , 0 0 1}$ \\
\hline Length of public roads in $\mathrm{km}$ & $\mathbf{0 , 5 6 4}$ & $\mathbf{0 , 2 9 3}$ & $\mathbf{0 , 4 6 1}$ & $\mathbf{0 , 6 3 9}$ & $\mathbf{0 , 4 2 5}$ \\
\hline p-value & $\mathbf{0 , 0 0 1}$ & $\mathbf{0 , 0 4 3}$ & $\mathbf{0 , 0 0 1}$ & 0,001 & $\mathbf{0 , 0 0 1}$ \\
\hline Length of public roads per $100 \mathrm{~km} 2$ & $\mathbf{0 , 4 3 8}$ & 0,484 & $\mathbf{0 , 3 1 5}$ & 0,196 & $\mathbf{0 , 3 5 3}$ \\
\hline p-value & $\mathbf{0 , 0 0 1}$ & $\mathbf{0 , 0 0 1}$ & $\mathbf{0 , 0 2 9}$ & 0,182 & $\mathbf{0 , 0 0 1}$ \\
\hline
\end{tabular}

Source: authors' own study based on CSO data.

Significant strong positive relations were found between the volume of investment outlays on public roads and the value of GDP and sold production in both cases per capita. However, the strength of interdependence varied, i.e. the largest was in the first years of Poland's membership in the EU, and the smallest was in 2009-2011. It can therefore be concluded that in the first years after Poland's accession to the EU, the most economically developed voivodships allocated the most funds for road line infrastructure. Such regularities were also seen in the last separate period, i.e. in the years 2015-2017. The years immediately preceding the Euro 2012 tournament completely reversed this rule. Roads were built and renovated in places where it was needed. In the case of the relationship between the amount of investment outlays and the length and density of public roads, the relations were very similar as for economic parameters. The larger road network was associated with the need to incur large expenses for its maintenance. The presented research results indicate a strong relationship between the economic potential and the existing density of the public road network with the amount of investment outlays for the construction and maintenance of this infrastructure. Only in the case of special needs, such as the organization of the Euro 2012 tournament, the rules were different, which involved the central financing of many road investments, important from the point of view of ensuring efficient communication during the championships.

The analysis of road infrastructure in Poland was carried out by Białek and Oleksiuk [2011]. The research concerned the earlier period (2003-2009) and only a part of roads, i.e. with hard surfaces. Similar results were obtained, so the highest dynamics of the increase in the length of roads was in the Podlaskie voivodship. Similar regularities concerned road density. However, the authors did not link the results of road construction with their financing. In turn, Korolewska [2012] carried out an analysis at the state level. The author compared the sources of financing for road transport infrastructure in Poland with other Member States. However, it did not link expenditure on roads with economic parameters. Bek [2011] in his considerations drew attention to the threats arising from European integration and the greater diversity that occurs. The measure of the region's competitiveness is the level of GDP per capita. The author also draws attention to the lower value of EU-financed projects per capita in the case of less developed regions. Żelechowski [2017] pointed out that differences in territorial disparities occur in many public services, such as Internet access, waste collection, etc. 
Obrębalski and Walesiak [2014] stated that development disparities apply to all areas of functioning, i.e. economics, standard of living, local community, infrastructure.

In studies on the costs of building road infrastructure and its links with the economy in other countries, similar results were obtained. Adu [2009] stated that financing of road construction contributes to easier flow of goods and services, which indirectly influences the acceleration of socio-economic development. Queiroz [2009] showed the relationship between the economic crisis and the financing of motorways. He also presented the possibilities of financing roads on the basis of public-private partnership. Cohen [2012] and the team based on the US market have shown that investments in roads are profitable. According to the authors, one dollar invested in roads in a short period of time allows to get two dollars from production and services. The economic benefits are greater during better economic times. According to the authors, even during an economic recession, expenditure on road infrastructure still causes positive effects in the economy.

\section{Conclusions}

Financing of linear road infrastructure in Poland was carried out mainly with the participation of EU funds. National funds were also available, including those spent by local governments. Investment outlays on roads apply to both the construction of new roads and the repair of existing ones. In 2005-2017, the length of public roads in Poland increased by $11 \%$ to $422,000 \mathrm{~km}$. Changes in individual voivodships varied. In relative terms, the most new roads were built in Eastern Poland (Podlaskie and Lublin), and the fewest in South-Western Poland (Opole). In addition, most roads were built in 20092011, regardless of voivodships. It was a period of preparation for the European Football Championships, which took place in Poland and Ukraine in 2012. Road expenses were very high in the run-up to the championships, in anticipation of heavy road traffic from football fans. After 2012, the level of expenditure decreased. The measurable effect of investing in road infrastructure is increasing the density of the road network in individual voivodships. There were disproportions in this respect, because the best density was found in the most economically developed voivodships, while the smallest had terrain obstacles in the form of lakes.

Investment outlays on public roads were related to the wealth of local governments, because the more economically developed voivodships spent more on roads, but also often had a more extensive road network. However, disparities in this respect were reduced, as evidenced by the decrease in the Gini coefficient in 2005-2017. Investment outlays on roads were more and more evenly distributed over individual voivodships. However, economic and road-related parameters were still of key importance. This was confirmed by the results of studies using the Pearson linear correlation coefficient. As a rule, a strong positive correlation was found between the volume of investment expenditure on public roads and the economic potential and existing density of public road networks. Only in the period immediately preceding Euro 2012 were different differences observed. They resulted from central financing of many road investments in the given period. 


\section{Bibliography}

Adu, J.: Financing and evaluation of investments in road infrastructure development. Doctoral dissertation, Kwame Nkrumah University of Science and Technology, Ghana, 2009, pp. 1-67.

Bailey D., Glasmeier A., Tomlinson P.R. Tyler P.: Industrial policy: new technologies and transformative innovation policies?, Cambridge Journal of Regions, Economy and Society, 12(2), 2019, pp. 169-177.

Bek J.: Zagrożenia w rozwoju województwa podkarpackiego w aktualnej sytuacji społecznogospodarczej kraju, Zeszyty Naukowe WSEI seria: EkonomiaA, 3(1), 2011, s. 213-234.

Białek J., Oleksiuk A.: Ocena i analiza infrastruktury drogowej w Polsce w ujęciu regionalnym w świetle wykorzystania funduszy Unii Europejskiej, Autobusy: technika, eksploatacja, systemy transportowe, 12, 2011, s. 57-69.

Cohen I., Freiling T., Robinson E.: The economic impact and financing of infrastructure spending, Associated Equipment Distributors, Washington, 2012, pp 1-49.

GDDKiA: Raport o stanie technicznym nawierzchni sieci dróg krajowych na koniec 2018 roku, Warszawa marzec 2019.

GUS: Transport - wyniki działalności w 2017 r., Warszawa, Szczecin 2018.

Korolewska M.: Wydatki publiczne na infrastrukturę transportu lądowego w Polsce, Studia Bas, 4, 2012, s. 79-124.

Obrębalski M., Walesiak M.: Terytorialny wymiar polityki rozwoju regionalnego województwa dolnośląskiego w latach 2014-2020, Prace Naukowe Uniwersytetu Ekonomicznego we Wrocławiu, 331, 2014, s. 96-105.

Program budowy dróg krajowych na lata 2014-2023 (z perspektywą do 2025 r.), Załącznik do uchwały nr 156/2015 Rady Ministrów z dnia 8 września 2015 r.

Queiroz C.: Financing of road infrastructure, In Proceedings of the $5^{\text {th }}$ Symposium on Strait Crossings, Trondheim, Norway, June 21-24, 2009, pp. 45-57.

Rozporządzenie Ministra Transportu i Gospodarki Morskiej z dnia 2 marca 1999 r. w sprawie warunków technicznych jakimi powinny odpowiadać drogi publiczne i ich usytuowanie, Dz. U. z 2016 r. poz. 124.

Strategia Zrównoważonego Rozwoju Transportu do 2030 roku, Ministerstwo Infrastruktury, Warszawa 22 marca 2019 r.

Tyc T. P.: Finansowanie infrastruktury transportowej w Polsce $\mathrm{z}$ wykorzystaniem europejskich funduszy inwestycyjnych i strukturalnych, Autobusy 6/2017, s. 1286-1293.

World Economic Forum: The Global Competitiveness Report 2017-2018, Genewa 2017.

Ustawa z dnia 21 marca 1985 r. o drogach publicznych, Dz. U. z 2018 r. poz. 2068.

Ustawa z dnia 23 października 2018 r. o Funduszu Dróg Samorządowych, Dz. U. z 2018 poz. 2161 .

Ustawa z dnia 27 października 1994 r. o autostradach płatnych oraz o Krajowym Funduszu Drogowym, Dz. U. z 2018 r. poz. 2014.

Żelechowski M.: Terytorialne dysproporcje dostępności usług publicznych w Polsce jako wyzwanie dla polityki spójności, Prace Naukowe Uniwersytetu Ekonomicznego we Wrocławiu, 465, 2017, s. 166-172.

\section{Finansowanie liniowej infrastruktury drogowej w Polsce}

\section{Streszczenie}

Celem głównym pracy było rozpoznanie i przedstawienie sytuacji oraz zmian w poziomie wydatków na drogi publiczne. Badania dotyczyły Polski, z uwzględnieniem podziału na województwa. Dane dotyczyły lat 2005-2017. Źródła materiałów stanowiła analiza dostępnej 
literatury z zakresu transportu drogowego, akty prawne, dane z bazy danych GUS. W pracy wykorzystano metodę porównawczą, posługiwano się wskaźnikami dynamiki, obliczono współczynnik koncentracji Giniego oraz przedstawiono stopień koncentracji za pomocą krzywej Lorenza. Zastosowano również współczynniki korelacji liniowej Pearsona. Do prezentacji wyników badań zastosowano metodę opisową, tabelaryczna i graficzną. Nakłady inwestycyjne na drogi dotyczą zarówno budowy nowych dróg, jak również naprawy już istniejących. W latach 2005-2017 długość dróg publicznych w Polsce wzrosła o $11 \%$ do 422 tys. km. Zmiany w poszczególnych województwach i latach były zróżnicowane. Największy przyrost dróg nastąpił w województwach podlaskim i lubelskim, a najmniejszy w opolskim. Największe nakłady inwestycyjne na drogi publiczne poniesiono w latach 2009-2011, co było związane z przygotowaniem do turnieju piłkarskiego Euro 2012, który odbył się w Polsce i na Ukrainie. Nakłady inwestycyjne były związane z poziomem rozwoju gospodarczego województw oraz z zasobem dróg publicznych. Jedyny wyjątek od tej reguły wystąpił w latach 2009-2011, gdy centralnie finansowano wiele inwestycji drogowych.

Słowa kluczowe: infrastruktura, transport drogowy, wydatki na drogi, fundusze europejskie JEL Codes: E22, H41, H54, O18, R40

Information about the authors:

\section{Dr hab. inż. Tomasz Rokicki}

Szkoła Głowna Gospodarstwa Wiejskiego w Warszawie Instytut Ekonomii i Finansów

Katedra Logistyki

ul. Nowoursynowska 166

02-787 Warszawa

e-mail: tomasz_rokicki@sggw.edu.pl

ORCID: 0000-0003-3356-2643

\section{mgr. Stanisław Bereziński}

Szkoła Głowna Gospodarstwa Wiejskiego w Warszawie Szkoła Doktorska

Instytut Ekonomii i Finansów

Katedra Logistyki

ul. Nowoursynowska 166

e-mail: stanisław_berezinski@sggw.edu.pl

ORCID: 0000-0003-4971-0137 